ROCZNIKI HUMANISTYCZNE

Tom LXIX, zeszyt $9-2021$

DOI: http://doi.org/10.18290/rh21699-6

PAWEŁ BIELICKI

\title{
THE IMPORTANCE OF HONG KONG IN THE POLITICAL AND ECONOMIC STRATEGY OF THE CHINESE COMMUNIST AUTHORITIES UNDER XI JINPING
}

\begin{abstract}
A b s tract. The aim of the article is to present and analyse the importance of Hong Kong in the political and economic strategy of the communist authorities in China under Xi Jinping. I am going to try to answer the question of whether China's policy towards the Special Autonomous District has changed after the President of China came to power. I have decided to present this topic as a result of the discussions in the discourse on the future of Hong Kong in the era of Chinese expansionist policy. In the text, I analysed the main determinants of the relationship of both entities and the increasingly frequent attempts to undermine the autonomy that Hong Kong has enjoyed for over 20 years. During Xi Jinping's rule, the new secretary general of the Central Committee of the Communist Party of China, aims to accelerate the process of unifying this area with mainland China, recognizing it as the first stage in gaining China's position as a global superpower. The main thesis of the article assumes that from the beginning of Xi's rule in power, the Chinese communists recognized Hong Kong as one of the most important problems in Beijing's political strategy. Therefore, they took specific steps to strengthen control over the province. The authorities in Beijing believe that only strict control over the Hong Kong people will enable a strong influence for China in international events, strengthening its position in the time of a possible confrontation with the United States. The main research paradigm used in the text is the system analysis method.
\end{abstract}

Keywords: China; Hong Kong; Beijing; Xi Jinping; USA; strategy.

\section{INTRODUCTION}

The SARS COV-2 coronavirus pandemic, which started at the turn of 2019-2020 in China and then spread to the whole world, resulted in the deterioration of the international situation in various parts of the globe. One

Pawee Bielicki, PhD - Asia and Pacific Society, Toruń; correspondence address - email: bielicki11@gmail.com; ORCID: https://orcid.org/0000-0002-5015-6869. 
of such areas has become Hong Kong, previously a British colonial area, and since 1997 a part of the People's Republic of China with special rights. Under the agreement between London and Beijing of December 1984, it is to have a certain degree of autonomy from the central government until 2047. In this article, I would like to describe the importance of Hong Kong in the political strategy of the Chinese communist authorities after 2013 and Xi Jinping's accession to power, who takes a completely different course in relation to this area than its predecessors. The aim of this paper is to indicate the most important conditions and dependencies of the new China's president's policy towards Hong Kong by presenting, among others, his attitude to the "umbrella revolution" of 2014 and the social protests of 2019 and 2020. I am going to trace the internal and external reasons for his decision and radical steps to limit civil liberties. The questions concern China's policy towards Hong Kong until 1984. What directions did Beijing take towards this area after its incorporation into the PRC from July 1, 1997 to the end of 2012? What was President Xi's attitude towards this area at the beginning of his reign? Has the "umbrella revolution" changed the priorities of China's internal and foreign policy? What were the international reactions to this protest? Why after $2016 \mathrm{Xi}$ decided to tighten the course towards the Special Administrative Region? How did the 2019 protests affect China's policy towards Hong Kong? Why did the secretary general of the Central Committee of the CPC decide to pass a new extradition law in July 2020?

\section{THE GENESIS OF THE PROCESS \\ OF INCORPORATION OF HONG KONG INTO CHINA: THE SIGNIFICANCE OF THE REGION FOR CHINESE DIPLOMACY}

When discussing the problem of the significance of Hong Kong in the internal and external policy of the Middle Kingdom after 2013, we should go back to the 1940s and 1950s, when after many years of civil war between the nationalists associated with the Kuomintang party and its leader, Chang KaiShek, and communists, led by the head of the Communist Party of China, Mao Zedong, - the latter took the reins in October 1949. The new government aimed to restore China's superpower status, drawing attention to the need to unite a country which was until recently divided and under humiliating control of the West that was afraid of an increase in the global expansion of the Middle Kingdom due to its economic, population and 
cultural potential. In the case of Hong Kong, the situation was so complicated that from 1898 its area was "leased" by Great Britain. In an effort to finally regulate its status, the authorities did not want to accelerate the unification process too much, due to China's many economic difficulties and Mao's ambition to become an absolute dictator in the country he governed. The situation was complicated by the isolation of Beijing on the international stage due to the conflict with the United States and the Soviet Union. In 1959, the year preceding the Soviet-Chinese split and the Great Leap Forward campaign in China, the head of the CPC decided that they should not put too much pressure on the Brits on Hong Kong as long as it could be valuable and useful to China and constitute a kind of bridge between the West and China (Osińska 340-341). Although the Cultural Revolution temporarily inhibited the process of its emancipation, it was with the sharp deterioration of Chinese-Soviet relations after the border clashes by the Ussuri River in 1969 and the normalization of relations between Beijing and Washington in February 1972 after the visit of US President Richard Nixon in China - that in London, the view that colonialism was a thing of the past was increasingly emphasized. The talks on the unification of Hong Kong with China significantly accelerated at the turn of the 1970s and 1980s after Deng Xiaoping came to power in Beijing. The new Chinese leader, striving to open up China to the world while maintaining the authoritarian political system, believed that the unification of Hong Kong with China would significantly contribute to the economic growth of the Middle Kingdom and encourage foreign investors to further economic involvement in the country he governs. In addition, the Great Britain, in the era of growing industrial problems, was aware of the need to maintain good relations with Beijing in this area. That is why in 1979 the then governor of Hong Kong, Murray MacLehose, travelled to Beijing. Although the visit was supposed to concern mainly the development of potential economic cooperation, he also discussed the future of the area under British jurisdiction that he administrated (Zamęcki, Rewolucja parasolkowa). Official negotiations began in September 1982, and in December 1984, British Prime Minister Margaret Thatcher and Zhao Zyiang, head of the governmental cabinet in the PRC, signed a "joint declaration" on this matter which was implemented in May 1985 (Żakowski 88). The pacification of the student revolt in Tianamnen Square on June 4, 1989 by the Chinese People's Liberation Army inhibited for some time the mutual relations between China and Great Britain and, more broadly, with Western countries. In addition, the last 
governor of Hong Kong, Chris Patten, made a decision in 1992 on a political reform aimed at increasing the representativeness of the Hong Kong parliament (Cabestan 58-59), but the arrangements previously contained in the declaration remained in force. Finally, on July 1, 1997, Hong Kong became part of the territory of China, becoming, along with Macao, a special administrative region of the PRC (SAR-special administrative regions) (J. Chan 571).

Following Hong Kong's incorporation into China, the authorities in Beijing faced significant challenges. Although at the turn of the $20^{\text {th }}$ and $21^{\text {st }}$ centuries the Chinese economy grew at a rate of over ten percent annual growth, China still did not show any significant diplomatic activity on the international arena. The Chinese communists realized that in order to strengthen their global position, the country needed economic growth, maintaining social control and cementing the domination of a relatively weak state in the Far East at that time. The incorporation of Hong Kong into China above all influenced their internal situation. It undermined the nature of the Chinese state which previously was strictly unitary and centralized (Gawlikowski). Moreover, it should not be forgotten that many institutional arrangements continued to be based on British legislation guaranteeing the protection of property rights and intellectual property. If they were violated, it was possible to defend their rights in the courts, unlike in mainland China. Therefore, as Małgorzata Bonikowska and Bruno Surdel rightly emphasized, Hong Kong remained the centre of operations related to copyright, design services and technology transfer (Bonikowska and Surdel 5). At that time, it became more and more important in the global economy, which was reflected in the seventh position in the ranking of the inflow and outflow of foreign direct investment in 2006, second only to the United States, Great Britain, France, Germany, mainland China and Japan, and in the region only China, whose direct investments accounted for $36 \%$ of all of them (Jankowiak 267). There is no doubt that the unfavourable social comparisons between the PRC and Hong Kong, Japan and Western Europe were a stimulus for the CPC leadership to pay special attention to economic modernization and not class struggle, as it was under Mao's rule (Larson 334). However, this does not change the fact that from the turn of the century, China wanted to take full control over Hong Kong, as evidenced by the attempt by the government in 2003 to introduce legislation that specified "treason, secession, rebellion, subversion" as an action against the Beijing authorities. The above action was protested by the Hong Kong society in July 2003 (Zamęcki, Sinizacja 18-19). Despite their efforts to subjugate the 
SAR, CPC representatives acted inconsistently in this matter. It can even be said that while the subdued policy towards Hong Kong has suited authorities in Beijing for long time due to the need to raise Western capital necessary for the economic development of the Middle Kingdom, since Xi Jinping has took power in November 2012 and stabilized China's position as one of the main actors on the international stage, Zhongnanhai (the government's decision-making centre in Beijing-P.B.) recognized that even at the price of a certain limitation of Hong Kong's relations with the foreign financial system, it was necessary to accelerate the adaptation of Chinese law to this territory.

\author{
THE FIRST YEARS OF THE RULE OF XI JINGPING \\ AND HIS POLICY TOWARDS HONG KONG \\ IN AN INTERNATIONAL CONTEXT: \\ THE “UMBRELLA REVOLUTION” AND ITS CONSEQUENCES
}

From the beginning of the new Chinese president's rule, it became clear that he would seek to curb Hong Kong's autonomy, but it was not yet clear when and how he wanted to achieve his goal. Wishing to change the policy towards the region, Xi identified the belief that the democratic system in the country could lead to destabilization and the possibility of losing power by the CCP, which in his opinion had the only real mandate to rule in China and in areas he considered to be part of China. This leader expressed the view that only a homogeneous, ideologically cohesive society could lead to the implementation of the government's intentions about the "Chinese dream". In order to achieve this, he had to first consolidate his position. Even before assuming formal reign, in April 2012, Xi contributed to the loss of office and freedom by Bo Xilai, secretary of the Shanghai party committee, one of the most important contenders in the power struggle. He and his wife were accused of corruption and abuse of power. A similar fate befell other communists who opposed Xi's aspirations to absolute power. During the following two years, there was a large-scale anti-corruption campaign which aimed, on the one hand, at improving the image of power in society and, on the other hand, at strengthening the rule of the new leader. The party's purges also seem to have exemplified a change in the foundations of Chinese diplomacy. Previously, supporters of the previous leaders continued to play an important role in the leadership, including Deng and Jiang Zemin, who 
claimed that China did not have the appropriate instruments in 2013 to allow it to act aggressively in the external arena. Admittedly, it was Xi's predecessor $\mathrm{Hu}$ Jintao who sparked Beijing's increased assertiveness in international diplomacy (Blumenthal), however, it was only the new leader who clearly specified his intentions. The proof was the direct reference to the elements of the "Chinese dream". The president suggested modifying the country's current development plan, paying more attention to the creation of a "moderate prosperity" society by 2021 and the "revival of the Chinese nation," which clearly meant that he aims at Sinocentrism and China's dominant role in the world in his foreign policy (Lubina 53). The new leader's agenda meant abandoning Deng's 24-sign doctrine of waiting in foreign policy for the right moment to attack and not flaunting his international politics. It was not without reason that $\mathrm{Xi}$ came to the conclusion that the full surrender of Hong Kong will be the first step in obtaining a position of international leadership, capable of absolute dominance in the Far East, to stop the activity of the United States in the Pacific and further their expansion to other territories, particularly in Europe and the Middle East. To this end, even in the first months of his rule, Xi unambiguously suggested that the people of Hong Kong and Macao should limit their aspirations to democracy, paying more attention to the general interests of the country and its regions, caring for long-term prosperity and stability (Xi Jinping 63-64). The Chinese government has also created an extensive catalogue of generally understood principles of "national security". They allowed for far-reaching persecution of the opponents of the system ("Beijing's 'Red Line" "), which raised concerns among the international community that the provisions in question could be applied in Hong Kong.

Another manifestation of the new approach of Beijing to Hong Kong was a report presented to the National People's Congress by Prime Minister Li Keqiang in March 2014. It is significant that as long as the previous head of government Wen Jiabao, who could not be considered a person with a liberal attitude, spoke of "a high degree of autonomy" of the area and that "the Hong Kong nation rules in Hong Kong," the new prime minister only recalled the principle of "one country, two systems," mentioning the need for "full and correct implementation of the constitution". Chinese Prime Minister also suggested that it is essential to strengthen cooperation between Mainland China and Hong Kong and Macao in order to "strengthen competitiveness" and further modernization of both China and the two provinces (Yuen, "Under the Shadow of China" 73-74). The omission of the terms 
concerning autonomy and independence of Hong Kong clearly meant that the goal of the Beijing authorities is to further tighten its supervision over it, but at that time it was not that easy to implement these plans. However, changes progressed in the economic sphere. Realizing Hong Kong's position as an international financial centre, the rulers of mainland China sought to increase economic influence and reduce Western economic involvement in the region, rightly viewing it as a means of putting pressure on Beijing. The signal of changes was the proposal expressed in 2013 to the Hong Kong authorities by Li Jinying, the state manager of China Resources Power and one of the new president's closest supporters, to restore Chinese control over two electric companies. Under this proposal, in January 2014, the State Grid Corporation of China, China's largest state-owned utility company, purchased $18 \%$ of Hong Kong Electric shares, making it the second largest electricity supplier for the area (Yuen, "Under the Shadow of China" 72). At the same time, Chinese authorities and the Hong Kong administrator also decided to trade shares between the markets, which meant that Chinese investors would be able to buy and sell shares of selected companies listed on the Hong Kong stock exchange (Lam, Chinese Politics 154). It is definitely true that the step taken by the Communists was an attempt to further merger the economies of China and Hong Kong, which raised concerns about making attempts to further restrict its autonomy and free trade with Western countries. These predictions proved right a few months later.

An extremely important issue for the consolidation of the international position of China has become the "umbrella revolution" in September 2014, when Hong Kong came to mass protests against the government, seeking after 2017 to push a person supported by Beijing to the governor seat. Discussions about the shape of the committee to identify this policy started as early as in spring 2013, but there were significant differences between actors in the selection procedure and the number of members of the nominating committee. Therefore, since the middle of that year, demonstrations of protesters demanding to maintain the existing order have intensified (Kwieciński 114), they were spontaneous demonstrations that did not contribute significantly to the existing situation. Given the dissatisfaction, the communists launched a "public consultation" in December 2013. During the negotiations, they hinted that the commission must be "patriotic," which should be reflected in the nomination of candidates for this institution previously approved by Beijing. They would represent all major sectors industry, commerce, social services and religious structures (J. Chan 573). 
Such an attitude of the communists did not earn the approval of the protesters who, however, did not have a significant public support. They were afraid that during the civil referendum scheduled for the second half of June, they would not get the 100,000 votes needed to push through its organization (Hui 113). The spark of rebellion was sparked by students who avoided making direct reference to political issues during their colonial years (C.-P. Chan 886). However, they noticed that as a result of the systematic limitation of civil rights by the administration in Zhongmanhai, only their active activity could contribute to stopping this trend. Even before the "umbrella revolution" broke out, the adoption by Beijing on June 10, 2014 of a white paper on the practice of "one country, two systems," in which the new direction of Chinese policy towards Hong Kong is clearly visible. In some way supplementing the previously quoted words of Prime Minister Li, who ignores the autonomy of Hong Kong, the government specified that he had general jurisdiction over Hong Kong, and the principle of two systems applies to "one country," which is to make China aware of the dominant role in this area. The authors of the document explicitly stressed that the most important principle in the concept of "one country, two systems" is to maintain China's sovereignty and its security, which may be violated by external forces and a "very small number" of people. Using traditional communist phraseology, the authorities indicated that their powers had been extended to "prevent the entry of foreign forces and interference in Hong Kong affairs" ("The State Council Information Office"). Although, in the opinion of the British politician Lord Wallace Sailtare, in the view of the British government, the White Paper does not dispute the Sino-British Joint Declaration of 1984 (Summers 10), however, it must be noted that it was the next stage in the direct subordination of Hong Kong to Chinese Communists.

Protests on a massive scale were initiated in September 2014. The main reason for their brake out was the reduction of suffrage in Hong Kong by the Chinese authorities and the increasing pressures of Beijing expressed by Hong Kong administration in the choice of candidates, giving guarantee of "long-term prosperity and stability of Hong Kong and to maintain the sovereignty, security and development of the country's interests" (Zamęcki, "Hongkong" 140). Despite the fact that a relatively small number of people took part in the demonstrations, their main core were young people, representing the dissatisfaction also of wider social groups (Scobell i Gong 7). This meant a failure for Beijing, supporting pro-Chinese candidates in election campaigns at the local level since the mid-1900s (Lam, "The 
Umbrella Revolution"). Therefore, it is impossible to resist the impression that for some time Beijing was looking for a modus vivendi form with the protesters. In October 2014, the Hong Kong authorities met with students who called for the revocation of the decision of the Standing Committee of the National People's Congress of People's Representatives (NPCSC) of August that year, the abolition of functional constituencies and a clear timetable for achieving these goals. In response, the authorities have suggested Beijing to provide "impartial" report regarding the situation after the decision of the NPCSC made in August and pledged to maximize representativeness in the committee for nomination in the next round of consultations. They also implied the willingness to continue talks and work on the constitutional reform after 2017. However, the above proposals did not gain broad approval among students who found them unclear and nonbinding (J. Chan 7). Finally, after 79 days, the protests were suppressed by the police, which fuelled distrust towards Beijing on a scale that has not been recorded since 1997 (Hui 116). Radical groups, including Hong Kong Indigenous, Demosisto, Hong Kong National Party or Youngspiration grew in strength, advocating programs to increase the subjectivity of the region, and in extreme cases its independence (Zamęcki, "Chiny na beczce prochu?" 299). They were a pretext for Beijing to provoke more radical actions of these circles in the future and to try to create a conviction in the international arena that their leaders are ordinary hooligans who are only interested in starting another riot. Fearing further open opposition from students, Beijing authorities continued to express concern that the spring 1989 youths' protests at Tiananmen Square, which threatened the loss of power by the communists, could be repeated. Regardless of the suppression of the then revolt, the Chinese authorities to this day try at all costs to erase the social memory about the events taking place at that time and did not allow the victims to be commemorated with dignity. For Chinese leaders, who see authoritarianism as the only way to govern society and ensure economic development, any vision of combining prosperity and democracy is pointless. Bearing in mind the students' protests of 1989, the collapse of post-communist regimes in Central and Eastern Europe, the collapse of the Soviet empire and the weakness of democratic governance in Europe and the US after 1991, the Xi regime believes that any relaxation of the conditions can contribute to political instability and economic chaos. In the case of Hong Kong, there is no doubt that a possible failure in the political and economic area will mean greater social inequalities, political instability and 
the risk of further regression of the economy, and the responsibility for this will fall on the authorities in Beijing (Bush, Hong Kong in the shadow 21). However, despite the above-mentioned protests, indicated by the Hong Kong and Beijing authorities as a threat to economic stability, the SAR economy in the first quarter of 2015 grew by $2.4 \%$ year to year, and the forecasts for the entire year were then speculated in the range from 1 to $3 \%$ (Hui 11). In the economic report for the third quarter of 2014, the government in Hong Kong, however, stated that the riots contributed to the disruption of business, among others in retail trade, catering and tourism (Scobell and Gong 9).

Another aspect important to illustrate the theme of this publication, were the reactions of the international attempts to limit the autonomy of Hong Kong. Since the beginning of the protests, the Chinese Communists accused the West of inspiring the riots, which could be due to Beijing's surprise with the scale of the protests (Loh 119-120) and Xi's fear that they will get out of control will not only limit the CCP's domination within the country, but also contribute to halt global offensive of the Middle Kingdom. Therefore, the Chinese media have repeatedly expressed the view that these protests are directed from above by Western instigators who want to destabilize China. The pretext for casting such hard accusations by the ruling authorities was a resolution enacted by the US Congress, calling on the authorities in Beijing to respect human rights within the area (A. Scobell and Gong 10). Although during President Obama's November 2014 meeting with Xi in Beijing, the former assured that Hong Kong's street protests were more of a manifestation of genuine widespread frustration with local problems than the result of any interference by Washington (A. Scobell and Gong 10), however, the words of the American president were not seen positively. The Chinese media continued to compare the protesters to "colourful revolutions and foreign interference" calling them "radical activists" seeking Hong Kong's independence (Yuen, "Hong Kong" 51). The Chinese rulers had little understanding of the awkward situation of Washington, forced to promote democratic values and support the protesters on the one hand, and the need to recognize that Hong Kong is part of China, and that the constitution is a document confirming China's sovereignty over it. Moreover, Washington is closely tied to Hong Kong in the economic sphere (Bush, "Hong Kong political reform"). The US, contrary to Beijing's views, did not actively support the protesters. All information including those about the activity of a Hong Kong America Center employee with ties to foreign activists and his meeting with the vice president of the National Endowment for Democracy, 
Louisa Greve, do not prove that Washington inspired protests from the outside (Bush, "Hong Kong political reform"). It can be assumed that the overt Chinese accusation of the American authorities of contributing to the destabilization of the country could have been conditioned by the desire to increase control over the country and the need to increase self-confidence of $\mathrm{Xi}$ in the face of Russia's annexation of Crimea and the war in eastern Ukraine in the first half of 2014. Being aware of the effectiveness of Russia's aggressive actions in its own sphere of influence, insufficient enforcement of sanctions imposed by the West on the Kremlin, divisions in Europe and the weakness of the United States, $\mathrm{Xi}$ concluded that since Vladimir Putin and his government did not suffer serious consequences for their actions, even more so China, closely tied to many of the world's economies, can allow itself to be bolder in the international arena. It can also be presumed that a Chinese president who does not know the West sufficiently and searches for conspiracies may actually believe that he is responsible for the attempt to destabilize Hong Kong and contribute to the deepening of China's distrust of the West, which may be difficult to overcome (Blackwill and Campbell). According to Marcin Adamczyk, people here still remember about the "age of humiliation" and fear that the West will intervene again under the pretext of respecting human rights, which may be associated with an attempt to break away - Hong Kong, Tibet or Xinjiang from the PRC (Adamczyk 90). That is why the Chinese Communists and the favorable domestic and foreign media, tried from the beginning of the protests in 2014 to induce the belief that China is a "victim," while being a reasonable and restrained superpower (Loh 132), and promoting a strong positive relationship between Hong Kong as well as Taiwan and Macau with mainland China. The ruling communists did not feel confident enough in the international arena. Due to the complicated Sino-American relations, the Taiwanese problem and the issue of increasingly bold nuclear provocations by the North Korean leader, Kim Jong Un, Xi tried to avoid direct tensions with the United States, bearing in mind that cooperation with Washington could result in an increase in the importance of the Chinese world economy. In order to continue and confirm economic aspirations, the Chinese leader continued the already ongoing intensive expansion of China in Africa and establishing new contacts with the countries of Central Asia and the Middle East. This was achieved through the concept of the New Silk Road, presented by Xi during his visit to Kazakhstan in October 2013 (Tomaszewski, "Nowy Jedwabny Szlak"). It aimed at launching infrastructural links between China and 
Europe, which in the long term is an actual threat to the dominance of the United States, because through economic investments in countries that initiative includes, China will have the chance to significantly strengthen its political position, which will inevitably lead to a depreciation of that dominance. In this situation, it can be concluded that the attempt to limit Hong Kong's autonomy was at that time only the first stage in the long-term strategy of Chinese diplomacy. As interpreted by the local researcher of international relations, Simon Shen Xu-hui, Beijing considered the question of holding potential elections in accordance with the broadly understood concept of "national interest" for the needs of the central government (Yuen, "Hong Kong" 52). That is why the American writer Suzanne Pepper did not unreasonably assess that the concept of "comprehensive jurisdiction" is to "make all interested parties believe that Hong Kong enjoys only the autonomy that Beijing is willing to grant” (,Section 4” 386). After all, the Chinese communists formally maintained the status quo. In 2015, Prime Minister Li assured that the government in Beijing would not tighten its policy towards Hong Kong, and the existing principles of autonomy will continue to be respected (Loh 126).

\section{THE CONSOLIDATION OF XI JINPING'S POWER AND THE ASSUMPTION OF THE OFFICE OF US PRESIDENT BY DONALD TRUMP: THE IMPLICATIONS OF THESE EVENTS FOR THE SITUATION OF HONG KONG}

Despite these assurances of the Chinese prime minister, the authorities continue to try to undermine the autonomy of Hong Kong. Since the end of the "umbrella revolution," it can be clearly seen that Beijing began to exert an increasing influence on the activities of so far independent political parties, trade unions, NGOs, educational institutions, the media and the entertainment industry (Beijing's "Red Line" 6). These actions resulted in an ongoing potential for further protests, as evidenced by the riots in February 2016 - the so-called "Fishball Revolution" in the Mongkok district (Scobell and Gong 8), which were quickly suppressed. It is possible that the protests and the changing international situation have resulted in accelerated attempts to limit Hong Kong's relative independence. Three events seem to have influenced such moves by Beijing - Xi's seizure of absolute power in China; the referendum on the exit of Great Britain from the European Union in June 
2016 and the election of Donald Trump as President of the United States in November of that year. The first of these meant the lifting by $\mathrm{Xi}$ of the informal limit of dual term in exercising power. This shift was unprecedented, as no leader since Mao's time had concentrated such strong political and personal power. $\mathrm{Xi}$ also began to promote a cult himself, which was repeatedly ridiculed in Hong Kong. According to "The South China Morning Post," based on the consensus form of leadership, existing since the days of Deng, has been abandoned in favour of often associated by Xi and a group of his closest associates system of centralized power (Góralczyk, "China under Uncle Xi"). The concentration of government in the hands of one person did not bode well for the independence of the SAR, as that person believes that only iron-fist rule will contribute to the growth of the CCP's importance internally and externally. Although Xi did not want to and cannot become an autocrat like Mao, he nevertheless strives to deepen the nationalism in Chinese society, which in his opinion seems to be necessary for building a united and strong China. Therefore, Hong Kong is becoming the main element of the planned transformation. According to Kerry Brown Xi, unlike his predecessors, he sincerely believes in the ideas he promotes, which gives him a kind of society-fostered authenticity (Brown, "Why Xi Jinping").

The second factor, concerning the British referendum, was important insofar as Beijing, due to Hong Kong's former colonial ties, still had to reckon with London's view of the future of this area to a greater or lesser extent. Admittedly, according to the Department of Trade and Industry, total trade between the two sides in 2015 was less than $1.5 \%$ of Hong Kong's total GDP, nevertheless in the long run, a possible depreciation of the pound could have led to complications in the British economy due to the decline in the number of Hong Kong tourists, and also affect the health of the Chinese economy (So, "Pros and cons"). One may get the impression that concern about the stability of the Chinese economy was behind the actions of $\mathrm{Xi}$, who said during his visit to London in October 2015 that he was against London leaving the EU (Brown, "What China Thinks"). In expressing such a view, the Chinese president, on the one hand, saw the possible exit of Great Britain from the Community as a threat to the unity of the European economy, which would have an impact on the Chinese economy, but on the other hand, he could notice that the importance of Great Britain in the newly emerging international configuration would also decline significantly at the end of Obama's tenure. Therefore, it cannot be excluded that Brexit and related consequences could be accepted in Zhangomanhai with calmness 
and a certain satisfaction, as it would weaken the British narrative and its instruments of influence on the situation in Hong Kong. In this situation, the Chinese president could afford to tighten the course towards Hong Kong, as evidenced by the election of Carrie Lam as the governor of this province. She represented pro-Chinese orientation and was advocate of limiting Hong Kong's efforts to deepen or maintain its autonomy. The proof of the above was her consent to increase the "patriotism classes" in Hong Kong schools in line with the Chinese narrative (Góralczyk, Wielki renesans 422).

The third element leading to the acceleration of the limitation of Hong Kong's autonomy was the election of US President Donald Trump in November 2016. From the beginning of his term in office, the new president and his administration strongly raised the issue of inequality in trade between Washington and Beijing, accusing Chinese communists of unfair practices in this matter. In order to change this status quo, it announced the introduction of customs duties on the most important Chinese goods from 2017, which was opposed against. The US government has also taken specific steps to limit China's expansion in the international arena, by trying to stop the activities of Chinese telecommunications companies, including Huawei, which Trump rightfully described as deepening the dependence of the American economy on the Chinese and intending to intensify Beijing's technological espionage in the United States. However the statements by the American president on Taiwan and a conversation with Tsai Ing-wen, the country's president in December 2016 were a much greater threat to the CCP (Pastusiak 185). Although he later did not take any specific actions for Taiwan, the actions of the president were treated in Beijing as a serious threat. For this reason, $\mathrm{Xi}$ soon began to prepare the ground for further sinicization in Hong Kong. In a speech in July 2017, to coincide with the $20^{\text {th }}$ anniversary of the handover to China of the zone, he said, "Hong Kong must improve its systems to uphold national sovereignty, security and development interests." He added that "any attempt to threaten China's sovereignty and security, questioning the power of the central government and the authority of the constitution of the SAR or the use of Hong Kong to carry out the infiltration and sabotage against China is an absolutely unacceptable act, crossing the "red line" (Beijing's ,Red Line” 8). A month later, in August 2017, Hong Kong's administrative leadership suggested increasing the punishment of three activists convicted a year earlier for participating in the umbrella revolution, Joshua Wong Chi-fung, Alex Chow Yong-kang and Nathan Law Kwun-chung. All three were accused of "unlawful assembly" 
(Dapiran 10). Beijing has also decided to withdraw its consent to the operation of the Hong Kong National Party, which has few supporters, but openly proclaims the necessity of Hong Kong becoming independent. This step was opposed by the United States, the United Kingdom and the EU which issued statements on the matter. In turn, a spokesman for the US consulate in Hong Kong said that the SAR government's decision to ban this political party was inconsistent with the values of freedom of expression and association ("Section 4" 388). Although Beijing has ignored Western opinion, it is correct to suppose that its aggressive actions arouse a growing sense of alienation between mainland China, Hong Kong and Taiwan during Xi Jinping's first term (Womack 13). The confirmation of this hypothesis materialized almost two years later.

\section{ORIGINS OF SOCIAL PROTESTS IN HONG KONG IN 2019}

\section{AND THEIR CONSEQUENCES FOR THE POLITICAL STRATEGY} OF BEIJING

The immediate cause of the social unrest that occurred in Hong Kong in mid-February 2019 was the government's announcement of a draft new extradition law. According to the rulers, it was expected to fill the gaps in the law. The planned regulations provided for clarification of the already existing ones regarding the extradition of criminals to China. An example is the 2018 murder case, where a Hong Kong man murdered his girlfriend in Taiwan and there were problems with his extradition as he could not be judged outside Hong Kong (Purbrick 466). However, both the Hong Kong population and Western observers saw that the new law could facilitate the extradition to Mainland China of those criticizing the CCP's policy and Xi himself. Protesters demanded that the proposed extradition bill be withdrawn, a commission to investigate whether the police were acting lawfully in suppressing the riots, an end to Beijing's use of the word "riot" in relation to the protests, and an amnesty for protesters and democratic elections of major legislative and executive bodies in Hong Kong, especially in the Legislative Council and its head (Bogusz, "Dylemat Pekinu"). The draft content of the submitted bill consists of an introduction and seven articles. The most important of them are Art. 2, 4 and 6. The first one relates to Beijing's opposition to interference from outside entities in the internal affairs of Hong Kong, especially the United States. The fourth article, on the 
other hand, describes that the Hong Kong enforcement will specify the "enforcement mechanisms" of the law to protect national security, without, however, specifying the details of these specifications. Art. 6, by contrast, gives the central government a free pass in the process of legal changes in Hong Kong and punishing any separatist or terrorist activities (Lim, "How Xi Jinping"). The tensions culminated in the events of June 12, 2019, when the police suppressed a protest by protesters, often using gang members and common criminals for this purpose (Boyajian and Cook). Finally, on July 9, Lam decided to suspend implementation into force of the Act, explaining that there are doubts from the public about the government's intentions ("Szefowa administracji Hongkongu"). Despite the Governor's speech, the protests continued. As the days went on, they began to become more and more uncoordinated and aggressive, causing them to end quickly. It is true that the intention of the protesters was to avoid direct clashes with the authorities and to move quickly from place to place in order to make it difficult to suppress the rebellion (Zamęcki, "Hongkong AD 2019" 145), it was obvious that, with the increasing brutalization of the Hong Kong police's actions, the protesters felt that in the situation of inevitable repression they had nothing to lose. Beijing's action was criticized by Amnesty International, which clearly indicated that the $\mathrm{CCP}$ was a disproportionate reaction to the events, which means another violation of human rights by Beijing (Zamęcki, "Chiny na beczce prochu?" 301). The governments of other countries also criticized the behaviour of the communists in the following months. The United States also reacted to the pacification. Back in March, the American Chamber of Commerce announced that Beijing's move could damage Hong Kong's reputation as a "safe haven in the international arena" (Purbrick 467). President Trump also spoke about this matter. Not paying attention to his words in the conversation on June 18, 2019, when he said he would not condemn Hong Kong's repression, and to his statement on August 1 of that year, when he told the press that the riots in Hong Kong were taking place between Hong Kong and China, "because Hong Kong is part of China" (Wright, "Pompeo's Surreal Speech") - however, in November 2019, he strongly supported the protesters, stating that he was doing it out of respect for President Xi ("Trump wsparł demonstrantów"). He also quickly signed two Hong Kong laws passed by the US Congress. The first one involved regular reporting by the State Department on the degree of autonomy of Hongkong, and it allowed for economic sanctions in case of using restrictions against opposition activists. Meanwhile, the second act obliges 
US authorities to ban Hong Kong's export of anti-protest agents, such as tear gas, rubber bullets and bang weapons. As you would expect, all of these steps taken by the US authorities provoked anger in Beijing and launched threats of possible "countermeasures" that might be taken by the Chinese authorities ("Trump wsparł demonstrantów"). A few months later, in May 2020, President Trump accused China of expanding the activities of the Chinese security apparatus in a place called "bastion of freedom" and of doing so in contradiction with the international agreements that had been already concluded by Beijing (China Moves 1 ).

It cannot be ruled out, however, that increased activity of the US administration on the issue of Hong Kong is mainly dictated by the rising tensions with China in the field of trade. Counting on major Beijing concessions on this matter, President Trump and his team express the hope that using Hong Kong protests to achieve their own political goals will contribute to China's more loyal economic behaviour and will halt or slow down its expansion in the Pacific. This may be confirmed in another statement by the American president, who said that if Beijing sends troops to Hong Kong, the trade agreement between China and the US may be hindered ("Hongkong byłby zmiażdżony"). It should also not be forgotten that the American administration, in criticizing the abuses of the Beijing authorities in the matter of human rights, is not consistent in similar cases, including in the context of Russia's attempt to poison the former FSB employee Sergei Skripal and his daughter, as well as the murder in Turkey of the journalist Jamal Hasody, who was in opposition to the heir to the throne, Prince Salman by the secret services of Saudi Arabia. In this case, Trump passed the agenda, openly saying that due to the oil supplied to the United States from the Saudis, Washington would do nothing about it (Zalewski, "'Saudi Arabia First"”). The same was with the issue of the Kurds, where the Americans found it more convenient to abandon them in the fight against ISIS because of their willingness to maintain relatively good relations with Ankara. Therefore, the actions of the main tenant of the White House towards Hong Kong should be treated only as an attempt to use demonstrators to obtain certain specific concessions from Beijing. Overall, the US authorities lack real political instruments to stop Beijing's actions. The situation is additionally emphasized by the fact that for over 30 years the Chinese have been gradually gaining more and more influence in American cultural and sports institutions, as evidenced by the fact that in 2019, Chinese companies threatened to cut off the funding of the National Basketball Association, following the entry of 
the CEO from Houston Rockets, expressing support for the protests in Hong Kong. NBA officials quickly apologized to the Chinese authorities, not wanting to lose access to the Chinese market (Rosenberger 149), which led to the perception that Americans found economic influence more important that civil rights in Hong Kong.

Hong Kong's social protests prove several things. It is fair to agree with Marcin Przychodniak, according to whom the freedom aspirations of Hong Kongers are in contradiction with Xi's policy, suggesting "a great revival of the Chinese nation" (Przychodniak, "Zmiany"), which he has been promoting since the beginning of his presidency. Therefore, the statement of the previously cited last colonial governor of Hong Kong, Chris Patten, is justified. He made it clear that since President $\mathrm{Xi}$ took power for life and intensified his cult of personality, there has been a significant change in Beijing's policy towards Hong Kong, and the issue of its freedom has become a priority for the future of mainland China (Lauge, David. "Highstakes"). Therefore, it is the authorities that will gradually limit the civil liberties of Hong Kong residents. On the other hand, as Marcin Przychodniak rightly describes, the rulers may also look for a scenario of ensuring the improvement of the material well-being of young people, acquiring land from development companies where apartments would be built for them. At the same time, a force scenario cannot be ruled out - the detention of the protesters and the ban on all gatherings. However, such a step would inevitably mean an increase in the number of deaths (Przychodniak, "Scenariusze"). In this situation, the Chinese are likely to continue using the tactics of manipulation of paying people trying to control the discussion about the protests on Facebook, Twitter and YouTube (Rosenberger 149) and removing subversive content from the Internet in mainland China (Taylor, Frantz and Wright 110). Xi's meeting with Lam in November 2019 was an expression of Beijing's support for the governor's actions. During the meeting, the president said that the party leadership had "confidence" in this politician and hoped that she would contribute to the restoration of "order," which remains the "most important duty" in Hong Kong (Bradsher, C. Buckley, "Xi Jinping Endorses"), and that she would punish those responsible for undermining "the protection of the welfare of the general public in Hong Kong" (Westcott, "Xi Jinping demands"). A similar tone in the speech of the Chinese leader was manifested in January 2020, even before the official confirmation of the coronavirus pandemic cases. Expressing his hope for the best for Hong Kong, the leader stressed that Hong Kong could only 
flourish if all social unrest was resolved. He also emphasized that building a stable and prosperous Hong Kong is a "common wish" of all Chinese people (Huifeng, "Xi Jinping says"). Beijing continues to struggle to suppress the movement as the Hong Kong protesters are a highly fragmented group with no leader. For example, the Civil Front of Human Rights, founded in 2002, unites a total of about 50 organizations calling for respect for human rights (Purbrick 475). This is a contradiction, for example, with the situation in Tianamnen Square during the students' protests in 1989, when leaders such as Fang Lizhi, Wu'er Kaixi and Wang Dan came to the fore. The lack of a centralized movement also limits the Chinese authorities' ability to influence individual groups and, possibly, to quarrel individual groups of students. While avoiding direct military confrontation with the opposition, Beijing is constantly introducing new legal provisions that may contribute to the collapse of democracy in this area. One of these projects aroused considerable controversy in spring 2020.

\section{LIMITING HONG KONG'S AUTONOMY IN 2020 \\ AND THE IMPACT OF THIS DECISION ON THE CONCEPT OF CHINA'S DOMESTIC AND FOREIGN POLICY}

China's policy towards Hong Kong intensified its activities and their radicalization at the turn of spring and summer 2020. In May of that year, as a result of the decision of the Standing Committee of the All-China People's Congress, pointing to the alleged increase in the threat to national security against Hong Kong, its vice-president Wang Chen, in his speech full of impertinence and half-truths, stated that the reason for the exacerbation of these actions by Beijing and the Hong Kong administration were the alleged appeals of oppositionists for its independent status, combined with their attacks on Chinese national symbols - the flag and state emblem, and incitement of Hong Kong citizens against the government, as well as supporting activists attacking Chinese government institutions and alleged actions to "discriminate and exclude" mainland Chinese citizens (China Moves 2). Soon after, on June 30, the authorities in Beijing, without any public consultations with residents and the Legislative Council, implemented the law on the national security of the Hong Kong Special Administrative Region. The document states that the Hong Kong administration is empowered to use instruments of control over any manifestation of political 
and social activity of the population contrary to Beijing's expectations. The Chinese authorities have also pushed through a controversial provision that shows that the opposition's activity can be considered a step leading to secession, subversive activity, terrorism and collusion with foreign forces. Significant clashes took place on the first day after the above regulations came into force in Hong Kong between protesters and the police (Bogusz, "Chiny wobec Hongkongu"), but they were suppressed.

By tightening its political stance towards Hong Kong, Beijing is trying to achieve several goals. First, with radical measures and measures to tackle the coronavirus pandemic in the first months of 2020 and the current problems of the United States and Western Europe in the fight against this disease, the Chinese communists intend to use the opportunity created to consolidate their primacy in Hong Kong without fear about international reactions. Assuming that the attitudes of the US and the West would be extremely subdued in this matter, $\mathrm{Xi}$ and his closest associates concluded that only a firm policy will be of benefit to Beijing. It is therefore necessary to say that China's actions did meet with a restrained reaction from the American administration, which despite having criticized its actions ("Administracja Donalda Trumpa"), clearly communicated that the United States will not prevent China from securing full control of its territory. Western Europe is also showing extreme caution in condemning the Chinese authorities. As stated by Jakub Jakóbowski, China wants to finally liquidate Hong Kong's autonomy, being aware that the US and the EU, plunged in with a pandemic, are unwilling and unable to use real instruments to stop Beijing's actions. The above analyst also claims that the Hong Kong problem was one of the most important challenges that the Chinese party leadership had been facing for several months ("Jakóbowski: Kryzys w Hong Kongu"). Another expert emphasizes that the law constructed by the communists will allow the prosecution of not only opponents within the SAR region, but also foreigners and people who are present in Hong Kong for a certain period, which may lead to arresting anyone who actively opposes China's policy around the world (Czubkowska, "Świecie"). It should not be forgotten that the authorities may use force at any time, but they will probably try to avoid this scenario, bearing in mind the likely internal and international complications after deciding to for such steps. Back in 1987, addressing members of the Hong Kong Basic Law Drafting Committee, Deng said that "after 1997, we will continue to allow the people of Hong Kong to verbally attack the Chinese Communist Party, but what if they transformed their word 
into action, trying to turn Hong Kong into the base of opposition to mainland China under the pretext of 'democracy'? Then we would have no choice but to intervene" (Huizhu, "Revisit").

Secondly, the reason for the sharpening of the course and the intensification of repression in Hong Kong is X's belief that in the face of the strengthening of his personal power and the unlimited terms of his term as Secretary General of the Central Committee of the CCP, the Chinese government should actively oppose the United States in all corners of the globe. The situation is facilitated by China's growing economic problems caused by the coronavirus pandemic and its social consequences, the presidential election campaign ahead of the vote scheduled for November 3, 2020, as well as Pompeo's not entirely diplomatic statements, suggesting active action against the Chinese Communist Party ("Pompeo: Komunistyczna Partia Chin"), which may mean that the American party wants to deprive the Chinese communists of power, and thus, for the Chinese government and society, it may be a threat to the territorial integrity of this country. In this situation, voices appear more and more often that US-China confrontation may be inevitable. It cannot be ruled out that the deepening of the lack of mutual trust, there is a serious risk of an accidental conflict that neither party wants. However, we must not forget that, in order to maintain the unity of the Chinese state and maintain power, Beijing will most certainly accept the American challenge and strive to defeat the United States. The increased confidence of Chinese politicians and analysts clearly shows that in their opinion they have serious arguments for a victory over Washington, and the Hong Kong issue is one of the first elements to strengthen its own bargaining position in the event of a confrontation.

Thirdly, through the acquisition of full control over Hong Kong, Beijing also tightens its stance towards Taiwan and tests the United States on whether they remain ready to defend the area against potential Chinese military intervention. The correct view is that for the Chinese leaders, the control over Taiwan is extremely important for the implementation of Xi's concept of the "great renaissance" of China, due to the economic and social potential of the territory. Shortly after Xi's statement in January 2019 suggesting that he would like to apply the same "one country, two systems" formula to Taiwan (Góralczyk, "Powrót Chin" 357), at the end of March, the mayor of the city of Kaohsiung Han Kuo-yu, visited Hong Kong and Macao, and the cities in mainland Shenzhen and Xiamen ( $\mathrm{Yu} \mathrm{80),} \mathrm{which}$ could have served to put more pressure on Taiwan from China. Therefore, all Beijing's steps towards Hong Kong are being closely watched in Taipei, as 
they may be a foretaste of what lies ahead of the Taiwanese if their country's territory is supposed to be incorporated into China (Góralczyk, Wielki renesans 422-423). It can be assumed that the Chinese side is afraid of a kind of Taiwanisation of Hong Kong, aimed at gaining far-reaching autonomy. It was not without reason that Łukasz Zamęcki wrote as early as in 2014 that a democratic Hong Kong would become a precedent for other regions of the country, which could lead to the democratization of the country and thus weakening the control of mainland China (Zamęcki, Sinizacja 183). The situation is complicated by the fact that still - from 2016 - the power in Taiwan is held by President Tsai Ing-wen, who was previously chairman of the Democratic Progressive Party, which proclaimed the need for the island's independence. It is legitimate to believe that if China grows in strength sufficiently, it will prioritize joining Taiwan, whatever it takes. Hence, one should agree with Bogdan Góralczyk, who claims that such a step will be taken in a different way than in the case of Hong Kong or Macao, and that only some cataclysm could modify this priority of Chinese diplomacy (Góralczyk, "Geostrategia Xi Jinpinga" 293).

Fourthly, the tightening of the course and the intensification of repression in Hong Kong are due to the fact that President Xi wants to strengthen his political position in the party, tarnished to some extent by the delayed reaction of the Chinese authorities to the now spreading coronavirus pandemic. Although China, unlike the United States and Western Europe, coped with it relatively well, it is possible that the party elite did not doubt whether the leader would be able to deal with the virus in the first phase of the spread of the disease. The Chinese leader's fears were evidenced by his absence from a party conference in the initial phase of the epidemic, when delegates were able to ask him questions about the authorities' actions to contain the spread of the coronavirus. Moreover, it should not be forgotten that China is also bearing economic costs as a result of the pandemic. Data for 2020 show minimal economic growth of $1 \%$ (Trykozko, "Kryzys jak żaden inny"”), which is the worst result since 1970. In this context, the Chinese president has a great responsibility to continue the pre-pandemic pace of growth. A significant slowdown may cause problems with the integrity of Tibet, Xinjang and Hong Kong, which, unlike the areas mentioned above, have greater political and economic independence. It is true that possible perturbations in these areas should not undermine the primacy of the Communist Party of China, but they may cause serious political and social costs (Pei 88). 
It seems, however, that by taking decisive steps towards Hong Kong, the Chinese authorities are forgetting the continued dependence on Western capital, without which it will be very difficult to continue reforms at the current pace. Particularly severe for Beijing may be the restriction by the United States and other Western European countries of Hong Kong's special economic status (Bogusz, "Chiny wobec Hongkongu"). As described above by Goralczyk, for 20 years the economy of this zone won all rankings of economic freedom, which was of use to Beijing, which wanted to maintain this status. The scientist claims that the future of Hong Kong's development will depend on the West, which can "punish" it through specific legal regulations ("Prof. Góralczyk: Chiny biorą Hongkong"). An undoubted problem for Beijing is also the fact that the United States is Hong Kong's second largest trading partner. The dimension of this cooperation may be proved by the fact that in 2018 trade in goods and services of these two entities amounted to USD 67.3 billion, and the total surplus is USD 33.8 billion (Boyajian and Cook). On the other hand, however, it should not be forgotten that Hong Kong has already been strongly integrated into the Chinese economy, as evidenced by its successive decline in importance in the Chinese economy. An expression of this trend are the data which show that in 1997 Hong Kong provided 16.5\% of China's GDP, and in 2018 only $3.5 \%$. As the aforementioned analyst rightly points out, the process of "Hong Kongization of the PRC" and progressive sinicization of the area is currently underway (Góralczyk, "Powrót Chin” 355).

\section{CONCLUSION}

To recapitulate these considerations, it should be stated that since the 1970s, the importance of Hong Kong in China's domestic and foreign policy has been gradually increasing, and is an initial stage in the long-term political strategy of Chinese diplomacy. Ensuring full control over it was a priority for any Chinese leader, but until 2013, successors of Mao Zedong lacked appropriate instruments and a strong will to materialize their intentions. Only Xi Jinping, abandoning the doctrine of Deng's international politics, decided that this is the moment when it is China that should actively and openly oppose US domination in the world. The leader of the Asian power is aware that without control over Hong Kong it will be difficult to achieve further political goals, based, inter alia, on joining Taiwan to China 
and primacy in all corners of the globe. However, it cannot be ruled out that with the slow increase in control over Hong Kong, Xi's efforts may be suspended for a while, as the president and his associates also see their country being insufficiently prepared for a potential clash with the United States. In addition, the possible election of Joe Biden for the US president in the November elections may lead to a verbal softening of Chinese rhetoric and further strengthening of the economic and military potential of the Middle Kingdom, because the democratic American administration will at all costs avoid any pretext to conflict with him. Much will also depend on the further economic consequences of the coronavirus pandemic. While China is currently in a better position than the United States and Western Europe, the economic implications for China may prove more severe than initially thought. Undoubtedly, Beijing is greatly facilitated by the growing US-European divergences on the political and economic levels, as well as the gradual reduction of the US's global involvement in the world, including in the areas of Africa and the Middle East. Although Washington declares that it will pay attention to the situation in Asia and actively counteract China's expansion, in reality the withdrawal of its army from these areas will lead to a situation where in such places a political void will be created, filled in a short time by Russia and mainly China, which may dominate there in the future due to the obvious conditions of their economic potential and their reluctance to infiltrate existing political issues. Therefore, taking complete control over Hong Kong is an attempt to actually oppose the external environment and it may have a chance of success during the following several years.

\section{BIBLIOGRAPHY}

Adamczyk, Marcin. "Wyznaczniki ewolucji chińskiej polityki zagranicznej zawarte w Białej Księdze Obrony (2014).” Zeszyty Naukowe Towarzystwa Doktorantów UJ, no. 3, 2017, pp. 81-101.

"Administracja Donalda Trumpa nie uznaje już Hongkongu za terytorium autonomiczne wobec Chin." Gazeta Prawna, 27 May 2020, www.gazetaprawna.pl/artykuly/1479684,administracjadonalda-trumpa-nie-uznaje-juz-hongkongu-za-terytorium-autonomiczne-wobec-chin.html. Accessed 22.07.2020.

Beijing's "Red Line” in Hong Kong. Amnesty International, 2019, pp. 1-46. www.amnesty.org/ download/Documents/ASA1709442019ENGLISH.PDF. Accessed 11.07.2020.

Blackwill, D. Robert, and Kurt M. Campbell. "Xi Jinping on the Global Stage Chinese Foreign Policy Under a Powerful but Exposed Leader.” Council Special Report, 2016, no. 74, pp.1-66. www.cfr.org/report/xi-jinping-global-stage. Accessed 03.08.2020. 
Bradsher, Keith, and Chris Buckley. "Xi Jinping Endorses Carrie Lam, Embattled Hong Kong Leader." The New York Times, 04 November 2019. www.nytimes.com/2019/11/04/ world/asia/china-xi-lam-hong-kong.html. Accessed 19.07.2020.

Blumenthal, Dan. "China's Steps Backward Began Under Hu Jintao.” FP, 4 June 2020, foreign policy.com/2020/06/04/china-xi-jingping-hu-jintao-aggression-ideology/. Accessed 03.07.2020.

Bogusz, Michał. "Chiny wobec Hongkongu: ‘jeden kraj, jeden system'”. 03 July 2020. OSW. Ośrodek Studiów Wschodnich, www.osw.waw.pl/pl/publikacje/analizy/2020-07-03/chinywobec-hongkongu-jeden-kraj-jeden-system. Accessed 08.07.2020.

Bogusz, Michał. "Dylemat Pekinu: jak zdławić protesty i ukarać Hongkong," 28 October 2019. OSW. Ośrodek Studiów Wschodnich www.osw.waw.pl/pl/publikacje/komentarze-osw/ 201910-28/dylemat-pekinu-jak-zdlawic-protesty-i-ukarac-hongkong, Accessed 06.08.2020.

Bonikowska, Małgorzata, and Bruno Surdel. Hongkong i Chiny. Jeden kraj-dwa systemy. Perspektywy dla biznesu. Centrum Stosunków Międzynarodowych, 2017, pp. 1-11.

Boyaijan, Annie, and Sarah Cook. "Democratic Crisis in Hong Kong: Recommendations for Policymakers," August 2019. Freedom House, Policy brief, freedomhouse.org/sites/default/ files/2020-02/08142019_UPDATED_FINAL_Hong_Kong_Democratic_Crisis_Brief.pdf. Accessed 01.08. 2020.

Brown, Kerry. "What China Thinks About Brexit." The Diplomat, 25 July 2016, thediplomat.com /2016/06/what-china-thinks-about-brexit/. Accessed 13.07.2020.

Brown, Kerry. “Why Xi Jinping Can’t Be a 21st Century Mao Zedong.” The Diplomat, 16 February 2016. thediplomat.com/2016/02/why-xi-jinping-cant-be-a-21st-century-mao-zedong/. Accessed 10.07.2020.

Bush, Richard C. Hong Kong in the shadow of China. Living with the Leviathan. Washington, Brookings Institution Press, 2016.

Bush, Richard C. "Hong Kong political reform: Implications for U.S. policy,” 28 September 2016. Brookings, www.brookings.edu/research/hong-kong-political-reform-implications-for-u-spolicy/. Accessed 15.07.2020.

Cabestan, Jean-Pierre. Polityka zagraniczna Chin. Wydawnictwo Dialog, 2013.

Chan, Johannes. "Hong Kong's Umbrella Movement." The Round Table. The Commonwealth Journal of International Affairs, no.6, 2014, pp. 571-580.

Chan, Che-Po. "PostUmbrella Movement: Localism and Radicalness of the Hong Kong Student Movement." Contemporary Chinese Political Economy and Strategic Relations: An International Journal, vol 2, no.2, 2016, pp. 885-908.

China Moves to Impose National Security Law on Hong Kong. Congregational Research Service, Washington, 04 June 2020. 1-3. Federation of American Scientists, fas.org/sgp/crs/row/ IF11562.pdf. Accessed 21.07.2020.

Czubkowska, Sylwia. „Świecie, miej się na baczności, nadchodza Chiny”. Oto jak budowana jest pierwsza cyfrowa dyktatura, 09 July 2020. Spider's Web, spidersweb.pl/plus/2020/07/ chiny-cyfrowa-dyktatura-rezim. Accessed 30.07.2020.

Dapiran, Antony. "Prosperity and Freedom: Hong Kong’s Dilemma." China Story Yearbook, 1-15, press-files.anu.edu.au/downloads/press/n4224/pdf/ch09.pdf. Accessed 19.07.2020.

Dylan Loh Ming Hui. “Hong Kong's Political Future After The 'Umbrella Revolution'.” Policy Raport, December 2015, pp. 1-13.

Gawlikowski, Krzysztof. "Procesy transformacji w ChRL," 1-61. SWPS Uniwersytet Humanistycznospołeczny, www.swps.pl/images/stories/dokumenty/ccaw/gawlikowski/03\%20AW\% 20Procesy\%20transformacji\%20w\%20ChRL.pdf. Accessed 02.07.2020. 
Góralczyk, Bogdan. "China under Uncle Xi." Aspen Review, issue 2, 2016, www.aspen.review/ article/2017/china-under-uncle-xi/. Accessed 19.07.2020.

Góralczyk, Bogdan. Wielki renesans. Chińska transformacja i jej konsekwencje. Wydawnictwo Dialog, 2018.

Góralczyk, Bogdan. "Powrót Chin do centrum światowej sceny." Rocznik Strategiczny 2018/19, no. 24,2019 , pp. 353-369.

Góralczyk, Bogdan. "Geostrategia Xi Jinpinga - Chiny ruszają w świat.” Rocznik Strategiczny 2016/17, no. 22, 2017, pp. 286-300.

"Hongkong byłby zmiażdżony w 14 minut." TVN24, 23 November 2019, tvn24.p1/swiat/donaldtrump-o-sytuacji-w-hongkongu-i-relacjach-z-prezydentem-chin-ra987602-2305601. Accessed 09.08.2020

Hui Tin-Bor, Victoria. "Hong Kong's Umbrella Movement: The Protest and Beyond." Journal of Democracy, vol 26, no. 2, 2015, pp. 111-121.

Huifeng, He. "Xi Jinping says he 'sincerely hopes for best' for Hong Kong in New Year's Eve message." South China Morning Post, 31 December 2019, www.scmp.com/news/china/ politics/article/3044146/chinese-president-xi-jinping-says-sincerely-hopes-best-hong. Accessed 03.08.2020.

Huizhu, Tan. Revisit Deng Xiaoping's speeches on Hong Kong - Part 1. CGTN, 01 September 2019, news.cgtn.com/news/2019-09-01/Revisit-Deng-Xiaoping-s-speeches-on-Hong-KongPart-1-JD7PX11V84/index.html. Accessed 18.06.2020.

"Jakóbowski: Kryzys w Hong Kongu to kolejny argument za uniezależnieniem od Chin (ROZMOWA)." 1 July 2020, Biznes Alert, biznesalert.pl/chiny-usa-ue-zaleznosc-gospodarczadywersyfikacja-oze-energetyka/. Accessed 04.08.2020.

Jankowiak, Anna. "Znaczenie ekonomiczne Hongkongu w rejonie Azji i Pacyfiku. Procesy integracyjne w regionie Azji i Pacyfiku." Prace Naukowe Uniwersytetu Ekonomicznego we Wroctawiu, no. 13, 2008, pp. 261-272.

Kendall-Taylor, Andrea, Erica Frantz, and Joseph Wright. "The Digital Dictators. How Technology Strengthens Autocracy." Foreign Affairs, no. 2, 2020, pp. 103-115.

Kwieciński, Rafał. Zjednoczenie Chin? Proces reintegracji Wielkich Chin na przełomie XX i XXI wieku. Księgarnia Akademicka, 2016.

Lam Wo-Lap, Willy, Chinese Politics in the Era of Xi Jinping: Renaissance, Reform, Or Retrogression. Routhledge, 2015.

Lam, Willy. "The Umbrella Revolution and the Future of China-Hong Kong Relations." La Lettre du Centre Asie, November 2014. Institut français des relations internationales, www.ifri.org/ sites/default/files/atoms/files/ifri_lettreducentreasiewlamchinahongkong112014final_copie.pdf. Accessed 14.07.2020.

Larson Welch, Deborah. "Will China be a New Type of Great Power?" The Chinese Journal of International Politics, vol. 8, issue 4, 2015, pp. 323-348.

Lauge, David. "High-stakes power play: Xi moves to subdue Hong Kong." The Japan Times, 26 May 2020. www.japantimes.co.jp/news/2020/05/26/asia-pacific/xi-jinping-china-hong-kong/. Accessed 27.06.2020.

Lim, Jonathan. "How Xi Jinping Thought Gave Hong Kong Its National Security Law." The Diplomat, 26 July 2020, thediplomat.com/2020/06/how-xi-jinping-thought-gave-hong-kongits-national-security-law/. Accessed 14.07.2020.

Loh, Dylan. "Defending China's National Image and 'Defensive Soft Power': the Case of Hong Kong's 'Umbrella Revolution." Journal of Chinese Political Science, no. 22, 2017, pp. 117-134. 
Lubina, Michał. "Rosja Władimira Putina a Chiny Xi Jinpinga. O wpływie przywódców politycznych na politykę w państwach autorytarnych: przypadki rosyjski i chiński." Nowa Polityka Wschodnia, no. 3, 2018, pp. 41-62.

Osińska, Małgorzata. “Znaczenie kolejnych lokalizacji przystani promów na wyspie Hongkong na tle przemian społecznych i kształtowania się lokalnej tożsamości.” „Politeja. Pismo Wydziału Studiów Międzynarodowych i Politycznych Uniwersytetu Jagiellońskiego, no. 46, 2017, pp. 329-351.

Pastusiak, Longin. “Zmienna polityka prezydenta Donalda Trumpa wobec Chin.” Kwartalnik Naukowy Uczelni Vistula 2018, no. 4, 184-193.

Pei, Minxin. "China's Coming Upheaval Competition, the Coronavirus, and the Weakness of Xi Jinping." Foreign Affairs, no. 3, 2020, pp. 82-95.

Pompeo: Komunistyczna Partia Chin stanowi główne zagrożenie naszych czasów. TVN24, 30 January 2020, tvn24.pl/swiat/pompeo-komunistyczna-partia-chin-stanowi-glowne-zagrozenienaszych -czasow-3646128. Accessed 11.08.2020.

"Prof. Góralczyk: Chiny biorą Hongkong. Czas na Tajwan?” Rzeczpospolita, 08 July 2020. www. rp.pl/Chiny/200709500-Prof-Goralczyk-Chiny-biora-Hongkong-Czas-na-Tajwan.html. Accessed 16.08.2020.

Przychodniak, Marcin. "Zmiany w chińskiej zasadzie 'jedno państwo, dwa systemy'.” 24 July 2019. PISM, Polski Instytut Sparw Międzynarodowych，www.pism.pl/publikacje/ Zmiany w_chinskiej_zasadzie_jedno_panstwo_dwa_systemy. Accessed on 03.07.2020

Przychodniak, Marcin. "Scenariusze polityki ChRL wobec protestów w Hongkongu." 22 October 2019. PISM, Polski Instytut Sparw Międzynarodowych, www.pism.pl/publikacje/ Scenariusze_polityki_ChRL_wobec_protestow_w_Hongkongu_. Accessed 20.06.2020.

Purbrick, Martin. "A Report Of The 2019 Hong Kong Protests." Asian Affairs, vol 50, issue 4, 2019, pp. 465-487.

Rosenberger, Laura. "Making Cyberspace Safe for Democracy." Foreign Affairs, no. 3, 2020, pp. 146-159.

Scobell, Andrew, and Min Gong. "Whither Hong Kong?” Rand Corporation, 2016, pp. 1-18.

"Section 4 - China and Hong Kong." U.S.-China Economic and Security Review Commission, www.uscc.gov/sites/default/files/2019-09/Chapter\%203\%20Section\%204-\%20China\%20and \%20 Hong\%20Kong_0.pdf, Washington, 2019,.382-411. Accessed 13.07.2020.

So, William. "Pros and cons for Hong Kong if the UK opts for Brexit." China Daily, 20 June 2016, www.chinadailyasia.com/opinion/2016 06/20/content_15450874.html. Accessed 30.06. 2020.

"Szefowa administracji Hongkongu Carrie Lam: Ustawa o ekstradycji jest martwa." Rzeczpospolita, 09 July 2019, www.rp.pl/Polityka/190709418-Szefowa-administracji-HongkonguCarrie-Lam-Ustawa-o-ekstradycji-jest-martwa.html. Accessed 10.08.2020.

Summers, Tim. "British Policy toward Hong Kong and its Political Reform." A Social Science Quarterly on China, Taiwan, and East Asian Affairs, vol 52, no. 4, 2016, pp. 1-25.

"The State Council Information Office of the People's Republic of China, Full Text: The Practice of the 'One Country, Two Systems' Policy in the Hong Kong Special Administrative Region." 10 June 2014. english.gov.cn, The State Council the People's Republic of China, english.www.gov.cn/archive/white_paper/2014/08/23/content_281474982986578.htm. Accessed 19.07.2020.

Tomaszewski, Wojciech. "Nowy Jedwabny Szlak," 15 May 2020. CSPA, www.polska-azja.pl, www.polska-azja.pl/w-tomaszewski-nowy-jedwabny-szlak/. Accessed 05.08.2020. 
"Trump wsparł demonstrantów z Hongkongu. Chiny zapowiadają "kontrposunięcia". TVN24, 28 November 2019, tvn24.pl/swiat/donald-trump-podpisal-ustawe-o-poparciu-dla-prodemokra tycznych-demonstrantow-w-hongkongu-ra988877-2314380. Accessed 19.07.2020.

Trykozko, Martyna. “'Kryzys jak żaden inny'. MFW obniża prognozy gospodarcze, ale Chiny będą na plusie, 24 July 2020. 300gospodarka.pl, 300gospodarka.pl/live/kryzys-jak-zadeninny-mfw-obniza-prognozy-gospodarcze-ale-chiny-beda-na-plusie. Accessed 11.07.2020.

Westcott, Ben. "Xi Jinping demands end to violent protests in surprise meeting with Hong Kong leader. CNN, 05 November 2019, edition.cnn.com/2019/11/04/asia/xi-jinping-carrie-lamhong-kong-china-intl-hnk/. Accessed 11.07.2020.

Womack, Brantly. "Xi Jinping and Continuing Political Reform in China." Journal of Chinese Political Science, no. 3, 2017, pp. 1-13.

Wright, Thomas. "Pompeo's Surreal Speech on China." The Atlantic, 25 July 2020, www.theatlan tic. com/ideas/archive/2020/07/pompeos-surreal-speech-on-china/614596/. Accessed 11.08. 2020.

$\mathrm{Xi}$, Jinping. The Govermance of China. Foreign Languages Press, 2014.

Yu, Ching-Hsin. "Taiwan in 2019: US-China-Taiwan Relations and Domestic Dynamics." Asian Survey, no. 1, 2020, pp. 79-84.

Yuen, Samson. "Hong Kong After the Umbrella Movement an uncertain future for 'One Country Two Systems'." China Perspectives, no. 1, 2015, pp. 49-53.

Yuen, Samson. "Under the Shadow of China: Beijing's policy towards Hong Kong and Taiwan in comparative perspective." China Perspectives, no. 2, 2014, pp. 69-76.

Zalewski, Tomasz. " 'Saudi Arabia First'. Trump uniewinnia księcia.” Polityka, 21 November 2018, www.polityka.pl/tygodnikpolityka/swiat/1772366,1,saudi-arabia-first-trump-uniewinniaksiecia.read. Accessed 27.06.2020.

Zamęcki, Łukasz. Rewolucja parasolkowa w Hongkongu. Przyczyny, przebieg, następstwa. Wydawnictwo Uniwersytetu Warszawskiego, 2018.

Zamęcki, Łukasz. "Hongkong AD 2019. Przyczyny i kierunki rozwoju protestów w Specjalnym Regionie Administracyjnym ChRL." Sprawy Międzynarodowe, no. 3, 2019, pp. 133-150.

Zamęcki, Łukasz. Sinizacja polityczna Hongkongu. Wydawnictwa Uniwersytetu Warszawskiego, 2019.

Zamęcki, Łukasz. "Chiny na beczce prochu? Protesty w Hongkongu w 2019 roku i ich przyczyny.”,Rocznik Strategiczny 2019/20, t. 25, 2020, pp. 292-304.

Zamęcki, Łukasz. "Sinizacja polityczna Hongkongu." Spoleczeństwo i Polityka, no. 3, 2014, pp. 173-199.

Żukowski, Karol. "Hongkong w nowej rzeczywistości.” Współczesne Chiny. Kultura - Polityka - Gospodarka, ed. Małgorzata Pietrasiak, Wydawnictwo Uniwersytetu Łódzkiego 2005.

\section{ZNACZENIE HONGKONGU \\ W STRATEGII POLITYCZNO-GOSPODARCZEJ CHIŃSKICH WŁADZ KOMUNISTYCZNYCH ZA XI JINPINGA}

Streszczenie

Celem artykułu jest przedstawienie i analiza znaczenia Hongkongu w strategii politycznej i ekonomicznej władz komunistycznych w Chinach za rządów Xi Jinpinga. Zamierzam spróbować odpowiedzieć na pytanie, czy polityka Chin wobec Specjalnego Okręgu Autonomicznego 
uległa zmianom po objęciu władzy przez prezydenta Chin. Niniejszy temat zdecydowałem się przybliżyć na skutek obecnych w dyskursie dyskusji odnośnie przyszłości Hongkongu w dobie ekspansywnej polityki chińskiej. W tekście przeanalizowałem główne determinanty, przedstawiające stosunki obu podmiotów i coraz częściej pojawiające się próby podważenia autonomii, którą cieszył się Hongkong przez ponad dwadzieścia lat. Xi Jinping, nowy sekretarz generalny Komitetu Centralnego Komunistycznej Partii Chin, w okresie rządów dąży on do przyspieszenia procesu unifikacji tego obszaru z Chinami kontynentalnymi, uznając to za pierwszy etap uzyskania pozycji Chin jako globalnego supermocarstwa. Główna teza artykułu zakłada, że od początku sprawowania władzy przez Xi chińscy komuniści uznali Hongkong za jeden z najważniejszych problemów w strategii politycznej Pekinu. Dlatego podjęli oni konkretne kroki na rzecz wzmocnienia kontroli nad prowincją. Władze w Pekinie uważają, że jedynie ścisła kontrola nad Hongkończykami umożliwi silny wpływ Chin na wydarzenia międzynarodowe, wzmacniając swoją pozycję w dobie ewentualnej konfrontacji ze Stanami Zjednoczonymi. Głównym paradygmatem badawczym, zastosowanym w tekście, jest metoda analizy systemowej.

Słowa kluczowe: Chiny; Hong Kong; Pekin; Xi Jinping; USA; strategia. 